\title{
Retention probability of purse seine grating sieve based on fish morphology
}

\section{Balık morfolojisine göre gırgır boylama eleğinin alıkoyma olasılığı}

\author{
Zafer Tosunoğlu ${ }^{1}$ - Sinan Mavruk ${ }^{2 *}$ • Nazlı Kasapoğlu ${ }^{3}$ \\ ${ }^{1}$ Ege University, Faculty of Fisheries, Izmir, Turkey \\ ${ }^{2}$ Çukurova University, Fisheries Faculty, 01330, Balcalı, Adana, Turkey \\ ${ }^{3}$ Central Fisheries Research Institute, Trabzon, Turkey \\ https://orcid.org/0000-0002-1168-9611 \\ https://orcid.org/0000-0003-1958-0634 \\ (D) https://orcid.org/0000-0001-5526-778X
}

\section{How to cite this paper:}

Tosunoğlu, Z., Mavruk, S. \& Kasapoğlu, N. (2021). Retention probability of purse seine grating sieve based on fish morphology. Ege Journal of Fisheries and Aquatic Sciences, 38(2), 173-180. DOI: 10.12714/egejfas.38.2.06

Abstract: The retention-releasing patterns of the double-grid grating sieve placed on the deck of the purse seiners were revealed for four case species (Sardina pilchardus, Sardinella aurita, Engraulis encrasicolus and Boops boops) using a simulated data predicted from total length (TL) - maximum height (Hmax) and TL - maximum width (Wmax) regressions. To calculate these relationships, samples were collected during commercial purse seine operations between 3 April 2017 and 21 March 2018 in Izmir Bay, Aegean Sea (Turkey). Optimal Bar Spacing (OBS) values corresponding to minimum landing sizes or the length at first maturity were calculated separately for each species. OBS values were found $10.97 \mathrm{~mm}$ for sardine (Sardina pilchardus), $11.29 \mathrm{~mm}$ for round sardine (Sardinella aurita), $7.78 \mathrm{~mm}$ for anchovy (Engraulis encrasicolus) and $17.89 \mathrm{~mm}$ for bogue (Boops boops). The bar spacing regulations may constitute a promising management measure to release undersized fish for the purse seine fishery in the Aegean Sea.

Keywords: Aegean Sea, sieve selectivity, sardine, round sardine, anchovy, bogue

Öz: Gırgır teknelerinin güvertesine yerleştirilen çift ızgaralı eleğin alıkoyma-bırakma özellikleri dört tür (Sardina pilchardus, Sardinella aurita, Engraulis encrasicolus ve Boops boops) için toplam uzunluk (TL) - maksimum yükseklik (Hmax) ve TL - maksimum genişlik (Wmax) ilişkilerinden tahmin edilerek ele alınmış̧ır. Bu ilişkileri ortaya çıkarmak için, 3 Nisan 2017 ile 21 Mart 2018 tarihleri arasında İzmir Körfezi'nde (Türkiye) gırgır örneklemeleri yapılmış̧ır. Ele alınan türler için regresyon eşitlikleri tanımlandıktan sonra, Sechin'in seçicilik yaklaşımının bir uyarlaması kullanılarak, her bir türün farklı çubuk aralığındaki elekler tarafından yakalanma olasılıkları hesaplanmış̧ır. Sonrasında minimum yasal boy ya da ilk eşeysel olgunluk boyuna karşılık gelen optimal elek çubuk aralı̆ı (OECA) değerleri, her tür için ayrı ayrı hesaplanmıștır. OEÇA değerleri sardalya (Sardina pilchardus) için 10,97 mm, yuvarlak sardalya (Sardinella aurita) için 11,29 mm, hamsi (Engraulis encrasicolus) için 7,78 mm ve kupes (Boops boops) için 17,89 mm olarak bulunmuştur. Çubuk araliğı düzenlemeleri, Ege Denizi'ndeki gırgır avcılığı için yakalama boyunun altındaki balıkların serbest bırakılması için umut verici bir yönetim önlemi olabilir.

Anahtar kelimeler: Ege Denizi, elek seçiciliği, sardalya, yuvarlak sardalya, hamsi, kupes

\section{INTRODUCTION}

Purse seine is one of the most efficient gear for catching pelagic species that shoaled (Ben-Yami, 1994), providing an important part of world's total fisheries production (FAO, 2020). Although this gear targets single species detected by a sonar or echo sounder it mostly captures various species under the light source in the Aegean Sea. Purse seine is usually known as a non-selective fishing gear. As it generally targets small pelagic fishes, it uses small mesh size in the main body and bunt of the net.

In the purse seine fishery in Aegean Sea, a shoal of fish is either aggregated to artificial light or detected on the sonar. Then the purse seine vessel spills the net around the gathered fish to quickly encircle them within the purse seine net. In this way, the fish shoal is completely trapped by a long wall of netting. After setting the net, the gear is closed from the lower part by hauling the purse line. Until the volume of the net becomes smaller, the net is pulled out of the water and stacked back on the deck of fishing boat with the aid of the hydraulic power block and the crew (hauling). In the final process, the crowded fish piles are pumped to the main deck of the seiner.

The main target species of purse seine fishery are sardine, round sardine, bogue and anchovy which constitutes the largest part of the catch in the Aegean Sea (Tosunoğlu et al., 2018a, 2020). On the other hand, over 70 species of different morphological and biological characteristics are captured by the net which is always in contact with bottom while operating. Although, this fishery has a considerable number of bycatch and discard species, the present legislation about purse seine net defines neither a minimum mesh size nor a mesh shape (Anonymous, 2020). However, there are Minimum Landing Size (MLS) regulations for sardines $(11.0 \mathrm{~cm})$, anchovy $(9.0 \mathrm{~cm})$ and horse mackerels $(13.0 \mathrm{~cm})$, and $15 \%$ of undersized catch is permitted in terms of total weight for each species.

Purse seiners use the double-layer grid system to separate fish species from each other and to sort market size 
fish. Its usage and properties are not regulated by rules. Fishers started to use the system voluntarily about five years ago in the Aegean Sea. In general usage, $9 \mathrm{~mm} / 8-7 \mathrm{~mm}$ bar spacing grids are used to separate sardine (Sardina pilchardus) from anchovy (Engraulis encrasicolus) and 13 $\mathrm{mm} / 8 \mathrm{~mm}$ used for larger sizes of fish e.g. round sardine (Sardinella aurita), chub mackerel (Scomber colias), Atlantic mackerel (Scomber scombrus), bogue (Boops boops), bluefish (Pomatomus saltatrix) to separate from sardine (Tosunoğlu et al., 2020). The second grid (bar spacing 9-8-7 $\mathrm{mm}$ ) are also used to select undersized fish, particularly sardine. So far, no research has been found that investigated the retention patterns in these sorting grids for grading of sizes of fish species in different morphologies.

The body shape of fish may be the most important factor, necessary to understand the consequences of changes in purse seine sieve grid size in retention patterns of different species. Depending on the shape, the maximum width or height of a fish is expected to be equal or larger to the gap between the two bars of the sorting grid to retain the fish. Although width or height of the fish determines grid selectivity of the device, minimum landing size regulations are based on the total length. Width or height is more difficult to measure compared to the total length and taking these measurements may take longer time. On the other hand, these morphometrics can be converted from the length and used in selectivity calculations. In this sense, Sechin (1969) showed how the girth-converted length values be used in the calculation of gill net selectivity directly based on fish body shape.

Apart from the bar spacing of the barrier trap (Tosunoğlu et al., 2018b), there are only a few studies investigated the relationship between fish body shape and trawl cod-end mesh shape in Turkey (Tosunoğlu et al., 2003a; 2003b; Tokaç et al., 2016). In these studies, it has been attempted to determine the most appropriate mesh shape, bar spacing and hanging ratio for the major commercial fish species in accordance with their body shape. The fish morphology and mesh shape studies are also performed (Efanov, 1987; Matsushita and Ali, 1997; Mendes et al., 2006; Stergiou and Erzini, 2002; Brčić et al., 2018a, b). However, there is no study investigating the grid selectivity based on fish body shape in purse seine.

In this study, we investigated the retention patterns of the purse seine grating device based on the fish morphometry. Passing between the two bars is not directly related to the total length of the fish species, but the width of the fish, and sometimes to the height. For this reason, firstly the relationship between total length and maximum body width and maximum body height were fitted for the four mostly landed fish species; sardine, round sardine, anchovy and bogue in Aegean purse seine fishery. Then, the total length of the four fish species from various bar spacing, and the bar spacing corresponding to the MLS of these species were estimated.

\section{MATERIAL AND METHODS}

Fish samples were collected during purse seining operations on board Afala (23.4 m LOA, 420 HP) between 3 April 2017 and 21 March 2018. Fishing was conducted in the outer bay of the Izmir Bay in the eastern Aegean Sea (Figure 1). A total of eight operations were conducted in eight days at depths ranging between 35 and $58 \mathrm{~m}$ (Table 1). The purse seine net was used by Afala consists of 5 bulk and 1 bunt, resulting in length of $750 \mathrm{~m}$ and depth of $164 \mathrm{~m}$. Technical characteristics of the purse seine net used in this study was given by Tosunoğlu et al. (2018a). As the targeted species are small pelagic fishes such as sardine and anchovy, the mesh size of the purse seine net is $13 \mathrm{~mm}$. Therefore, we assume that there is no size and species selectivity through the meshes. After the fish school were crowded during hauling the net (bunt) by hand, a fish pump directly transfers the catch to the sieve. Overall dimensions of the sorting grid panels in the grating sieve were $190 \mathrm{~cm}$ in length and $95 \mathrm{~cm}$ in width with a $10^{\circ}$ angle attack. A vibrate motion was given to the sieve in order to perform successful selection process.

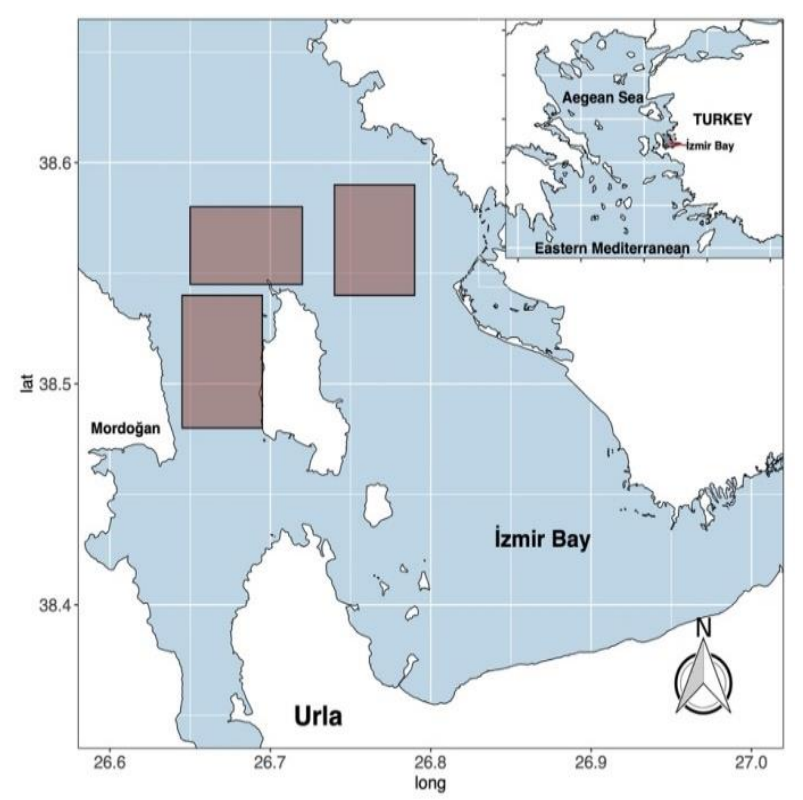

Figure 1. The map of sampling area

Table 1. Details of the purse seine operations where samplings were performed

\begin{tabular}{cccc}
\hline Date & Coordinates & $\begin{array}{c}\text { Depth } \\
(\mathbf{m})\end{array}$ & Time \\
\hline 03.04 .2017 & $38.64250^{\circ} \mathrm{N}-26.79583^{\circ} \mathrm{E}$ & 48 & $22: 30-00: 30$ \\
28.09 .2017 & $38.62500^{\circ} \mathrm{N}-26.76667^{\circ} \mathrm{E}$ & 40 & $05: 30-06: 30$ \\
28.10 .2017 & $38.62500^{\circ} \mathrm{N}-26.77778^{\circ} \mathrm{E}$ & 53 & $06: 25-07: 45$ \\
24.11 .2017 & $38.61944^{\circ} \mathrm{N}-26.80000^{\circ} \mathrm{E}$ & 35 & $06: 40-07: 50$ \\
26.12 .2017 & $38.60556^{\circ} \mathrm{N}-26.78889^{\circ} \mathrm{E}$ & 36 & $06: 50-08: 00$ \\
30.01 .2018 & $38.65278^{\circ} \mathrm{N}-26.68056^{\circ} \mathrm{E}$ & 58 & $07: 20-08: 35$ \\
23.02 .2018 & $38.58611^{\circ} \mathrm{N}-26.75556^{\circ} \mathrm{E}$ & 52 & $04: 18-06: 13$ \\
21.03 .2018 & $38.58056^{\circ} \mathrm{N}-26.72500^{\circ} \mathrm{E}$ & 53 & $06: 18-07: 34$ \\
\hline
\end{tabular}


The grating sieve consists of a double layer sorting grid panel. Small-sized fishes passed through the both grid bar spaces were directly release into the sea. In these panels, fishers use 13 or 14 and 8 or $9 \mathrm{~mm}$ bar spacing in upper and lower compartments for larger (bogue, mackerel, bonito etc.) and smaller (sardine, anchovy etc.) fish species, respectively. However, these spaces are not precisely arranged, and their gaps may reveal small differences from the nominal classifications. For this reason, the bar spacing of the sorting grids of the sieve were measured by using a digital calliper from upper, middle and lower lines (Figure 2). Then the average and standard deviations of bar spacing were calculated for each nominal class (Table 2).

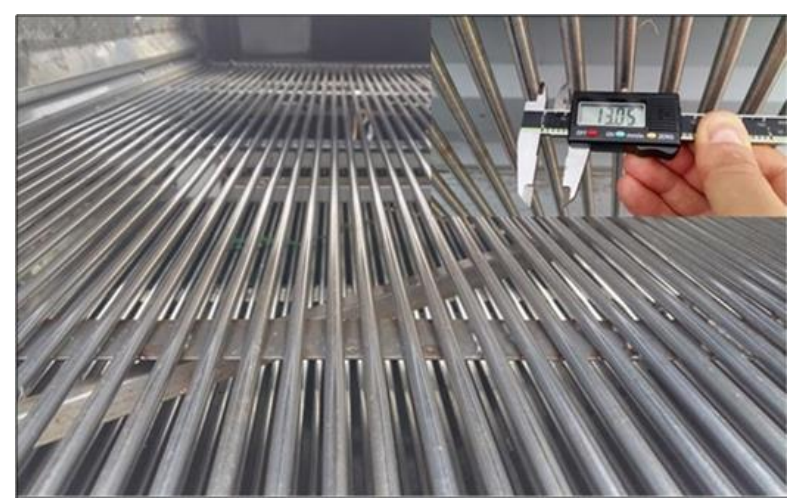

Figure 2. Double layer sorting grids of purse seine sieve and measuring bar space (top on the right)

Morphometric data was collected to determine the relevant dimensions of fish body in relation with bar spacing of various purse seine sieves. Total length (TL), the maximum height $\left(H_{\max }\right)$, the maximum width $\left(\mathrm{W}_{\max }\right)$ and the maximum girth $\left(\mathrm{G}_{\max }\right)$ of sardine, round sardine, anchovy and bogue, which were the most landed species in Aegean purse seine fishery, were measured to the nearest $\mathrm{mm}$ using a digital calliper rule. Girth measurements were taken by means of a tape measure at area of maximum cross-section of the body without applying any extra force. As minimum landing size (MLS) was forced on basis of TL, linear regressions were fitted between the $T L$ and the other measured dimensions of the fish using ordinary least-square regression (Zar, 1999).

Table 2. Descriptive statistics of the bar spacing of the purse seine sieve sorting grids

\begin{tabular}{lllllll}
\hline $\begin{array}{l}\text { Nominal Bar } \\
\text { Spacing }\end{array}$ & $7 \mathbf{m m}$ & $\mathbf{8} \mathbf{m m}$ & $\mathbf{9 m m}$ & $11 \mathrm{~mm}$ & $13 \mathrm{~mm}$ & $14 \mathrm{~mm}$ \\
\hline $\begin{array}{l}\text { Measured average } \\
\text { bar spacing }\end{array}$ & 8.0 & 8.3 & 9.0 & 11.1 & 13.0 & 13.6 \\
$\begin{array}{l}\text { Standard deviation } \\
\text { Range }\end{array}$ & 0.62 & 0.52 & 0.47 & 0.70 & 0.83 & 0.60 \\
Minimum & 3.5 & 2.9 & 2.9 & 4.9 & 5.1 & 2.8 \\
Maximum & 6.7 & 7.0 & 7.4 & 8.5 & 10.2 & 12.4 \\
$\begin{array}{l}\text { No. of measurement } \\
\pm \text { Confidence }\end{array}$ & 147 & 144 & 135 & 126 & 111 & 105 \\
interval (95.0\%) & 0.10 & 0.09 & 0.08 & 0.12 & 0.16 & 0.12 \\
\hline
\end{tabular}

The grid selectivity was calculated using an adaption of Sechins' morphometric approach (Sechin, 1969). Sechins' method originally suggested for calculating gill net selectivity based on an assumption of knife edge selection by the girth. Because of the variability in the girth at length relationship, this assumption cannot be directly applied to the length. To tackle this, Sechins' method calculates the probability of retention by length from the cumulative standard normal distribution (Hovgard and Lassen, 2000). In the case of grid selectivity, we rather used the fish width, the largest dimension of considered species and assumed that a fish is retained if the maximum width of body is larger than the grid size. The behaviour of the fishes passing through the sorting grids was not considered. For selectivity calculations, we predicted $W_{\max }$ and $H_{\max }$ values corresponding to a total length sequence from 0 to $25 \mathrm{~cm}$ using linear models, the details of which were given above. Then, the probability of retention ( $\left.P_{\text {retained}}\right)$ by length was calculated using the following formula (Hovgard and Lassen, 2000);

$$
P_{\text {retained }}=P\left(W_{\text {max }} \geq C\right)=1-\phi\left(\frac{C-K * D_{\text {max }}}{\sqrt{\sigma^{2}+\sigma_{c}^{2}}}\right)
$$

Here $C$ is the grid spacing, $K$ is the effect of compressibility of fish body and assumed as 1 in this study. $D_{\max }$ is the maximum dimension of fish which is $W_{\max }$ or $\mathrm{H}_{\max }$. $s^{2}$ is the mean squared error (MSE) of the Length- Dmax relationship and $s^{2} c$ is the standard deviation of the grid size measurements. "fi" is the cumulative standard normal distribution function. After we calculated the selectivity curves, we calculated the $L_{50}$ values and Optimum grid Bar Spacing (OBS) corresponding to minimum landing sizes (MLS) for $S$. pilchardus $(11 \mathrm{~cm}), S$. aurita $(11 \mathrm{~cm})$ and $E$. encrasicolus $(9$ $\mathrm{cm})$ and length at first maturity for $B$. boops $(13 \mathrm{~cm}$, Soykan et al., 2015) since there is no size limitation on the $B$. boops fishery. All calculations were performed in R Language and Environment for Statistical Computing (R Core Team 2019).

\section{RESULTS}

We measured six different sorting grid bar spacings of the purse seine grating sieve. The measured values of bar spacings were significantly different than the nominal bar spacings. The mean, minimum and maximum $\mathrm{TL}, \mathrm{H}$ and $\mathrm{W}$ values for four fishes were given in the Table 3. The $H_{\max }$ values of the fishes were highly significantly higher than $W_{\max }$ values in all species (paired sample t-test, $p<0.001$ ). Based on one-way ANOVA and Tukey post hoc test, W/H values did not significantly $(p<0.05)$ differed for the two sardine species, but it did for anchovy and bogue $(p<0.001)$. TL- $W_{\max }$ and TL$\mathrm{H}_{\max }$ regressions were presented in Figure 3 and the regression parameters were given in Table 4. 
Table 3. Descriptive statistics of the morphometric characters of fishes (TL: total length, $H_{\max }$ : maximum height, $W_{\max }$ : maximum width and $\mathrm{G}_{\text {max: }}$ maximum girth) in $\mathrm{cm}$

\begin{tabular}{|c|c|c|c|c|c|c|}
\hline & & $\bar{x}$ & sd & Min & Max & $\mathrm{Cl}(95.0 \%)$ \\
\hline \multirow{5}{*}{$\begin{array}{l}\text { Sardine } \\
(n=507)\end{array}$} & TL & 12.00 & 1.02 & 9.90 & 15.79 & 0.09 \\
\hline & $\mathrm{H}_{\max }$ & 2.00 & 0.19 & 1.60 & 2.79 & 0.02 \\
\hline & $\mathbf{W}_{\max }$ & 1.20 & 0.13 & 0.90 & 1.79 & 0.01 \\
\hline & $\mathbf{G}_{\max }$ & 5.70 & 0.72 & 4.20 & 7.89 & 0.06 \\
\hline & W/H & 0.59 & 0.04 & 0.52 & 0.74 & 0.003 \\
\hline \multirow{5}{*}{$\begin{array}{l}\text { Round Sardine } \\
(n=55)\end{array}$} & TL & 20.00 & 0.92 & 22.4 & 17.60 & 0.25 \\
\hline & $\mathrm{H}_{\max }$ & 3.40 & 0.17 & 3.70 & 3.00 & 0.05 \\
\hline & $\mathbf{W}_{\max }$ & 2.00 & 0.14 & 2.20 & 1.70 & 0.04 \\
\hline & $\mathbf{G}_{\max }$ & - & - & - & - & - \\
\hline & W/H & 0.58 & 0.03 & 0.52 & 0.64 & 0.01 \\
\hline \multirow{5}{*}{$\begin{array}{l}\text { Anchovy } \\
(\mathrm{n}=41)\end{array}$} & TL & 12.20 & 1.23 & 10.00 & 14.60 & 0.39 \\
\hline & $\mathrm{H}_{\max }$ & 1.70 & 0.24 & 1.10 & 2.10 & 0.08 \\
\hline & $\mathbf{W}_{\max }$ & 1.20 & 0.18 & 0.80 & 1.60 & 0.06 \\
\hline & $\mathbf{G}_{\max }$ & 4.70 & 0.73 & 3.20 & 5.80 & 0.23 \\
\hline & W/H & 0.70 & 0.05 & 0.60 & 0.76 & 0.02 \\
\hline \multirow{5}{*}{$\begin{array}{l}\text { Bogue } \\
(n=43)\end{array}$} & TL & 12.70 & 0.91 & 10.60 & 14.40 & 0.28 \\
\hline & $\mathrm{H}_{\max }$ & 2.70 & 0.28 & 2.00 & 3.30 & 0.09 \\
\hline & $\mathbf{W}_{\max }$ & 1.70 & 0.20 & 1.30 & 2.20 & 0.06 \\
\hline & $\mathbf{G}_{\max }$ & 7.60 & 0.80 & 5.20 & 9.20 & 0.25 \\
\hline & W/H & 0.65 & 0.03 & 0.59 & 0.71 & 0.01 \\
\hline
\end{tabular}

Table 4. Parameters of total length- maximum width and total length-maximum height regressions

\begin{tabular}{|c|c|c|c|c|c|c|c|c|}
\hline & Species & Par. & Estimate & Std. Error & $\mathrm{t}$ value & $\operatorname{Pr}(>|t|)$ & $\mathbf{R}^{2}{ }_{\text {adj. }}$ & MSE* \\
\hline \multirow{8}{*}{ TL-W $W_{\max }$} & \multirow{2}{*}{ S.pilchardus } & $a$ & 0.063 & 0.048 & 1.300 & 0.194 & \multirow{2}{*}{0.52} & \multirow{2}{*}{0.009} \\
\hline & & $\mathrm{b}$ & 0.094 & 0.004 & 23.650 & $<0.001$ & & \\
\hline & \multirow{2}{*}{ S.aurita } & $\mathrm{a}$ & 0.095 & 0.340 & 0.280 & 0.781 & \multirow{2}{*}{0.36} & \multirow{2}{*}{0.013} \\
\hline & & $\mathrm{b}$ & 0.094 & 0.017 & 5.544 & $<0.001$ & & \\
\hline & \multirow{2}{*}{ E.encrasicolus } & $a$ & -0.284 & 0.163 & -1.748 & 0.088 & \multirow{2}{*}{0.66} & \multirow{2}{*}{0.011} \\
\hline & & $b$ & 0.118 & 0.013 & 8.905 & $<0.001$ & & \\
\hline & \multirow{2}{*}{ B. boops } & $a$ & -0.239 & 0.310 & -0.771 & 0.445 & \multirow{2}{*}{0.49} & \multirow{2}{*}{0.021} \\
\hline & & $\mathrm{b}$ & 0.156 & 0.024 & 6.421 & $<0.001$ & & \\
\hline \multirow{8}{*}{$\mathrm{TL}-\mathrm{H}_{\max }$} & \multirow{2}{*}{ S.pilchardus } & $a$ & 0.216 & 0.058 & 3.740 & $<0.001$ & \multirow{2}{*}{0.66} & \multirow{2}{*}{0.012} \\
\hline & & $b$ & 0.152 & 0.005 & 31.640 & $<0.001$ & & \\
\hline & \multirow{2}{*}{ S. aurita } & $a$ & 0.373 & 0.301 & 1.239 & 0.221 & \multirow{2}{*}{0.65} & \multirow{2}{*}{0.010} \\
\hline & & $b$ & 0.151 & 0.015 & 10.033 & $<0.001$ & & \\
\hline & \multirow{2}{*}{ E.encrasicolus } & a & 0.127 & 0.293 & 0.435 & 0.666 & \multirow{2}{*}{0.4} & \multirow{2}{*}{0.035} \\
\hline & & $\mathrm{b}$ & 0.126 & 0.024 & 5.249 & $<0.001$ & & \\
\hline & \multirow{2}{*}{ B. boops } & $a$ & -0.350 & 0.372 & -0.941 & 0.352 & \multirow{2}{*}{0.61} & \multirow{2}{*}{0.030} \\
\hline & & $\mathrm{b}$ & 0.240 & 0.029 & 8.227 & $<0.001$ & & \\
\hline
\end{tabular}

*MSE: Mean Squared Error of the regression 

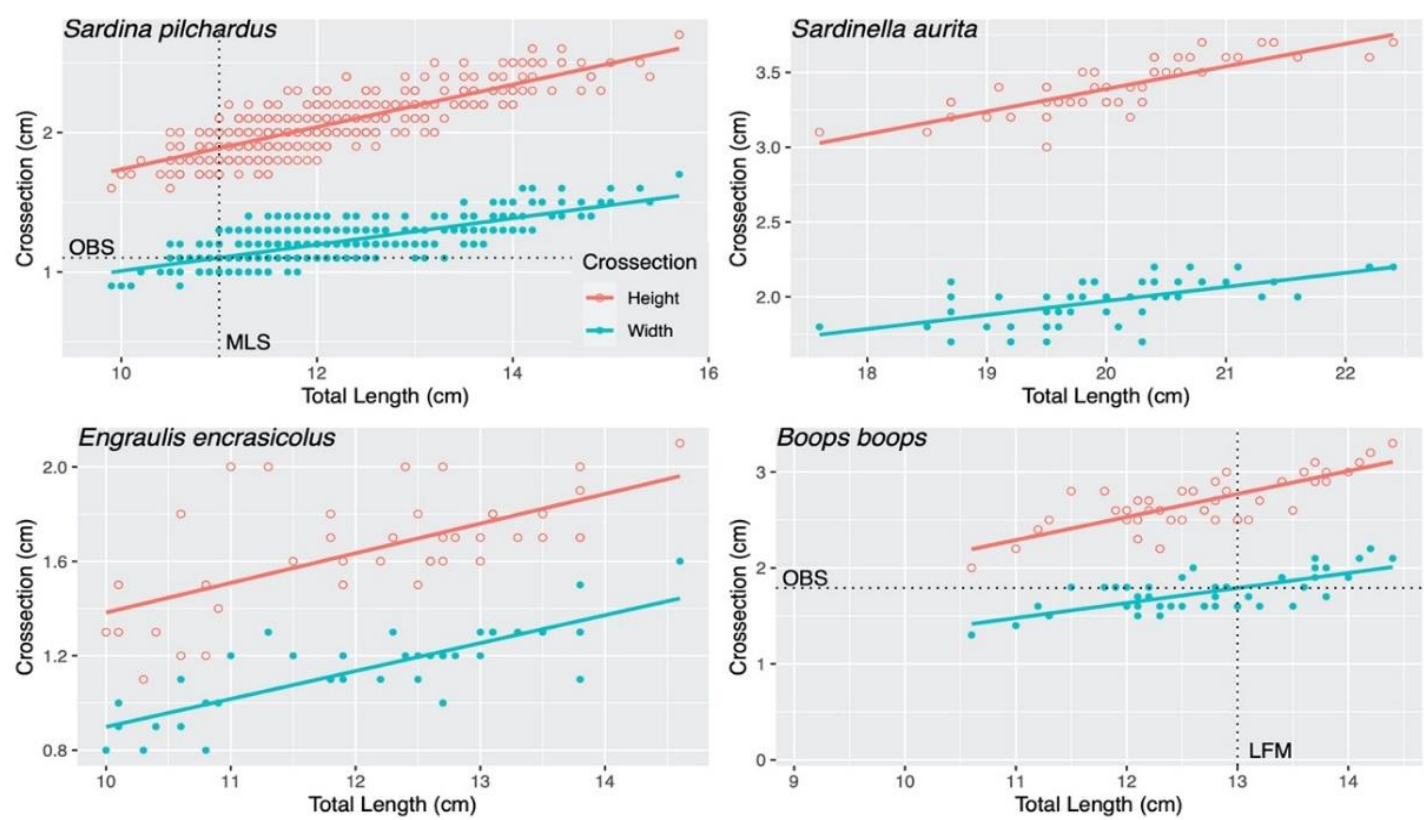

Figure 3. Total length-maximum width and total length-maximum height regressions (OBS: optimal bar spacing, MLS: minimum landing size, LFM: length at first maturity)

As the vibratory purse seine sieve eliminates the fish from its width, the maximum width of fish was taken as basis for estimating the selectivity parameters. $L_{50}$ values of all investigated species were larger in width-based selectivity parameters compare to the height-based (Table 5). Therefore, all estimated selectivity curves for each bar spacings were given as width-based in Figure 4 . From the table and figure, when the bar spacing of the purse seine sieves increases, the size selectivity of the fish also increases.
Optimal bar spacing values were found $10.97 \mathrm{~mm}$ for sardine, $11.29 \mathrm{~mm}$ for round sardine, $7.78 \mathrm{~mm}$ for anchovy and $17.89 \mathrm{~mm}$ for bogue. In our samples, all round sardine and anchovy individuals are larger than the length to be retained by their OBS. On the other hand, $9.7 \%$ for sardine and $39.5 \%$ of bogue individuals were smaller than the OBS. However, commercial loss percentages were calculated as $35.1 \%$ for sardine and $39.5 \%$ for bogue.

Table 5. L50 values of investigated species in different grid sizes assuming the retention by width and height

\begin{tabular}{llllll}
\hline & Grid & S. pilchardus & S. aurita & E. encrasicolus & B. boops \\
\hline \multirow{5}{*}{ by Width } & $\mathbf{s 7}$ & 7.81 & 7.51 & 9.17 & 6.65 \\
& $\mathbf{s 8}$ & 8.12 & 7.83 & 9.42 & 6.85 \\
& $\mathbf{s 9}$ & 8.86 & 8.57 & 10.01 & 7.29 \\
& $\mathbf{s 1 1}$ & 11.09 & 10.81 & 11.79 & 8.64 \\
& $\mathbf{s 1 3}$ & 13.1 & 12.83 & 13.39 & 9.86 \\
by Height & $\mathbf{s 1 4}$ & 13.73 & 13.47 & 13.90 & 10.24 \\
& $\mathbf{s 7}$ & 3.84 & 2.83 & 5.36 & 4.79 \\
& $\mathbf{s 8}$ & 4.04 & 3.03 & 5.60 & 4.92 \\
& $\mathbf{s 9}$ & 4.50 & 3.49 & 6.15 & 5.21 \\
& $\mathbf{s 1 1}$ & 5.88 & 4.89 & 7.83 & 6.08 \\
\hline
\end{tabular}




\section{DISCUSSION}

Sustainable fisheries management strictly anticipates that while fishing gears retain large fish in the catch, small juveniles are allowed to escape (Armstrong et al., 1990). Recently, there have been many studies aiming to improve towed gear selectivity by modifying gear design e.g. square mesh cod-end, escape panel and window, turned mesh and sorting grid (Lucchetti et al., 2015; STECF, 2015). Although, selectivity has been regulated by means of a legally defined minimum mesh size for many fishing gears conventionally, this is not convenient for the purse seine net. Therefore, use of sorting grids in the purse seine net (particularly in bunt) or sieve (on deck) is good solution for solving this problem.
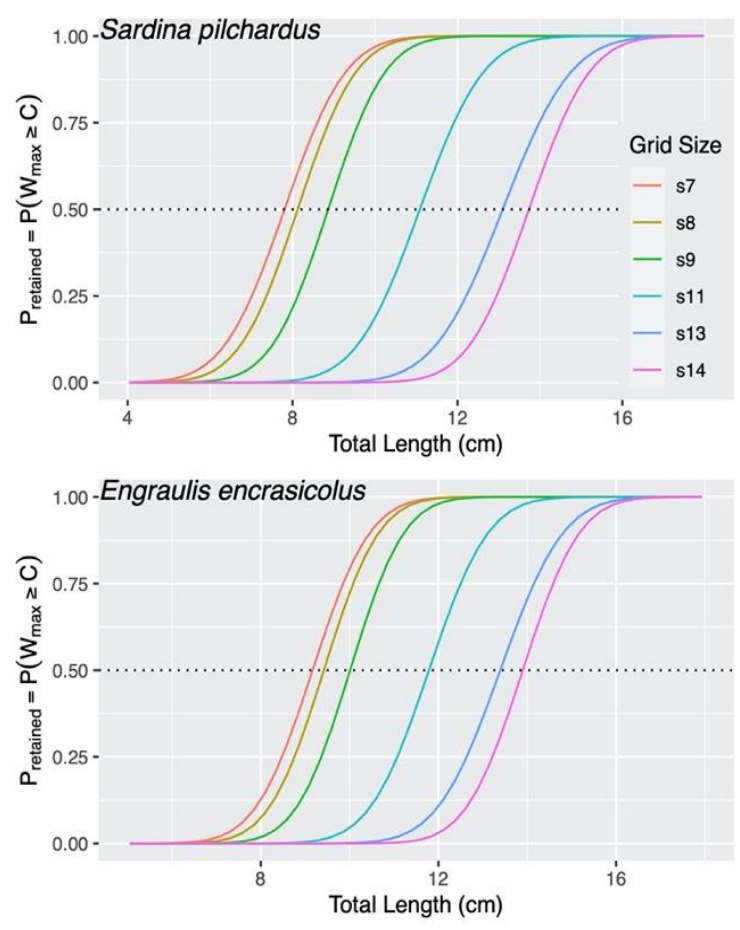

Studies related to sorting grids mounted on the purse seine bunt shown that while these devices gave successful results for escaping undersized mackerel, operational conditions have made them very difficult to use (Misund and Beltestad, 1994). In the Aegean Sea, purse seine fishers use grating sieve consisting of double layer sorting grid on the deck of the seiner to separate fish species from each other and large sizes of the same species from small ones successfully. Although, the purse-seine fishers satisfied with the operating performance of the sieve, the scientific baseline has not yet been established about selectivity of this device and the survival rate of the fish escaped. Therefore, this study is initially important because it empirically determines the optimal bar spacing from fish body morphology for the most landed fish species in purse seine fishery.
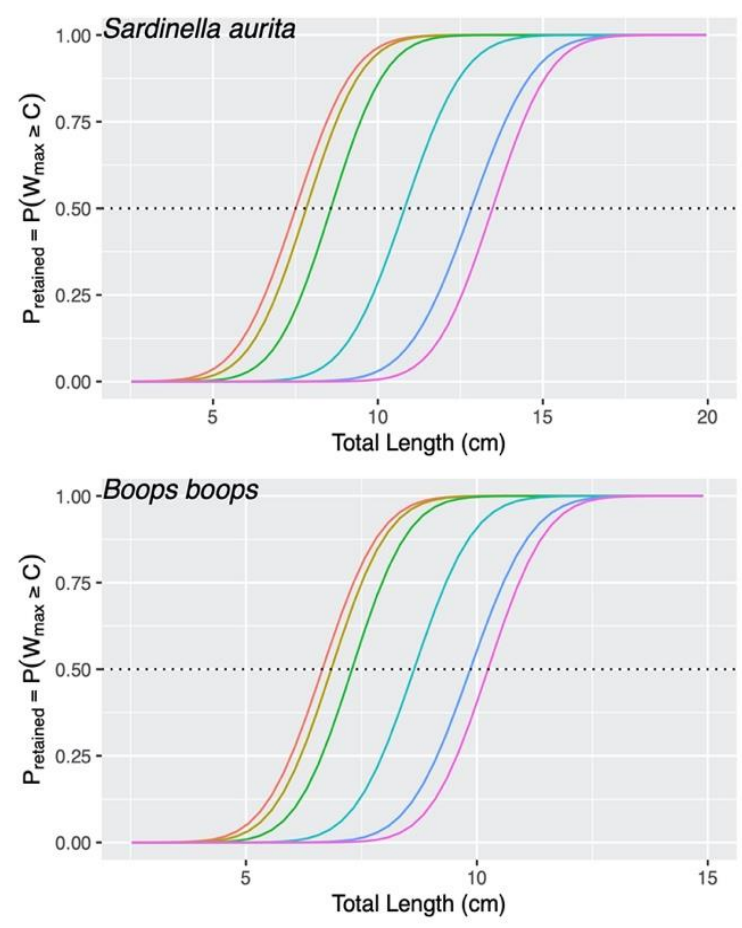

Figure 4. Selectivity curves of investigated species based on their maximum width

Diversity of fish caught in the purse seine is just like the demersal trawl which hinders the implementation of multispecies management (Tosunoğlu et al., 2018a, 2020). The reason is that there are many fish species that have different body shapes in the catch composition. For instance, sardine and gilthead sea bream have fusiform and laterally compressed body shapes, respectively. Width of sardine that corresponds to its enforced MLS is equal to $10.97 \mathrm{~mm}$ bar spacing. However, width of anchovy that correspond to its enforced MLS is equal to $7.78 \mathrm{~mm}$. In this case, the bar spacing arranged for sardine will result in significant loss of commercial sizes of anchovy. Bar spacing of the purse seine grating sieve could be most important management measure for the exploitation of target fish since there is no selectivity in the net. The optimal bar spacing $(10.97 \mathrm{~mm})$ for sardine, most landed species (53.7\%) in Izmir Bay purse seine fishery (Tosunoğlu et al., 2020), is thought to be suitable only for sardine with some commercial loses. However, this bar spacing is not suitable for anchovy (37.1\%) and bogue $(2.1 \%)$. In this situation, capture of all sizes of bogue and other larger size fishes e.g. mackerel and horse mackerels etc. below MLS is inevitable. Although other commercial fish 
species such as mackerel, chub mackerel, horse mackerel and bluefish are caught in Aegean Sea purse seine fishery, these are larger sized fishes, and they all are retained on the first grid of sorting sieve. Therefore, their retention probabilities were not considered in this study.

Juveniles including mackerel, horse mackerel, round sardine and other species recruited to the fish stocks from the middle of March to end of the season (15 April) were caught by purse seiners in the Izmir Bay and other bays of the Aegean Sea (Cihangir and Ünlüoğlu, 2015). It is inevitable that the catch of these juveniles, especially those who move with sardine and anchovy shoal under the light vessel or detected by the sonar. For this reason, prevention of juvenile fish catch seems to be technically very difficult. Although it is possible to overcome this problem with the use of a grading sieve with suitable bar spaces in purse-seine fishing in the Aegean Sea.

Organizing and performing purse seine selectivity trials requires an important time, resources and effort. For this reason, we firstly used a morphometry-based approach to define the selectivity patterns of sorting sieve bar spacings in this preliminary study. This seems a promising approach in the management of data-poor fisheries. Although, this approach provided us quick exploratory results, further studies are required to understand which variables affect

\section{REFERENCES}

Anonymous. (2020). Notification 5/1. The commercial fish catching regulations in 2020-2024 fishing period. Republic of Turkey Ministry of Agriculture and Forestry, General Directorate of Fisheries and Aquaculture, Ankara (in Turkish).

Armstrong, D. W., Ferro, R. S. T., Maclennan, D. N. \& S. A. (1990). Gear selectivity and the conservation of fish. Journal of Fish Biology, 37, 261262. DOI:10.1111/j.1095-8649.1990.tb05060.x

Ben-Yami, M. (1994). Purse seining manual. Oxford, UK: A Division of Blackwell Scientific Publications Ltd.

Brčić, J., Herrmann, B. \& Sala, A. (2018a). Predictive models for codend size selectivity for four commercially important species in the Mediterranean bottom trawl fishery in spring and summer: Effects of codend type and catch size. PLoS One, 13(10), e0206044,

DOI:10.1371/journal.pone.0206044

Brčić, J., Herrmann, B., Mašanović, M., Šifner, S.K. \& Škeljo, F. (2018b). CREELSELECT - A method for determining the optimal creel mesh: Case study on Norway lobster (Nephrops norvegicus) fishery in the Mediterranean Sea. Fisheries Research, 204, 433-440.

DOI:1016/j.fishres.2018.03.020

Cihangir, B. \& Ünlüoğlu, A. (2015). Status of small pelagic fishes in the Aegean Sea. In T. Katağan, A. Tokaç, Ş. Beşiktepe, \& B. Öztürk B (Ed.), The Aegean Sea marine biodiversity, fisheries, conservation and governance (pp. 303-323). Turkish Marine Research Foundation (TUDAV).

Efanov, S. F., Istomin, I.G. \& Delmatov, A. A. (1987). Influence of the form of fish body and mesh on selective properties of trawls. ICES C.M. 13.

FAO, (2020). FAO Yearbook. Fishery and Aquaculture Statistics 2018. http://www.fao.org/documents/card/en/c/cb1213t, DOI: 10.4060/cb1213t species and size selectivity as well as survival of selected individuals.

\section{CONCLUSION}

Every species investigated here shows a certain degree of difference in body shapes. For this reason, when the purse seine sieve selectivity is considered, maximum width of fish in relation to the maximum bar spacing could be a critical regulation measure. Regarding this issue, prediction with a simulation-based approach models developed by Herrmann et al. (2016) and Brcic et al. (2018a,b) have been applied to predict which sizes of fish are able to pass through the different bar spacing of the grating sieve in purse seine. As a result, determining or predicting the optimum bar spacing in the catching part of the purse-seine can be an effective fishing regulation method that provides maximum yield by avoiding juveniles.

\section{ACKNOWLEDGEMENTS}

The present study was funded by the Ege University Scientific Research Project Coordination Unit (Project No. 2017/SUF/002) and Ministry of Agriculture and Forestry, General Directorate Agriculture Research and Policies (Grant number: TAGEM/HAYSUD/2015/A11/P02/8). The authors would like to thank the captain and crew of purse seiner Afala and also researchers involved in the projects.

Herrmann, B., Larsen, R.B., Sistiaga, M.B., Madsen, N., Aarsæther, K.G., Grimaldo, E. \& Ingolfsson, O. (2016). Predicting size selection of cod (Gadus morhua) in square mesh codends for demersal seining: simulation-based approach. Fisheries Research, 184, 36-46. DOI: 10.1016/j.fishres.2015.07.015

Hovgard, H. \& Lassen, H. (2000). Manual on estimation of selectivity for gillnet and longline gears in abundance surveys. FAO Fisheries Technical Paper No. 397, 84 pp.

Lucchetti, A., Sala, A., Kholeif, S. \& Notti, E. (2015). Towards sustainable fisheries management. Nova Science Publishers, Inc., New York, 276 pp.

Matsushita, Y. \& Ali, R. (1997). Investigation of trawl landings for the purpose of reducing the capture of non-target species and sizes of fish. Fisheries Research, 29, 133-143. DOI: 10.1016/S0165-7836(96)00534-6

Mendes, B., Fonseca, P. \& Campos, A. (2006). Relationships between opercula girth, maximum girth and total length of fish species caught in gillnet and trammel net selectivity surveys off the Portuguese coast. Journal of Applied Ichthyology, 22, 209-213 DOI: 10.1111/j.1439-0426.2006.00734.x

Misund, O. A. \& Beltestad, A. K. (1994). Size selection of mackerel and saithe in purse seine. ICES CM, 1994/B:28.

Sechin, Y. T. (1969). A mathematical model for the selectivity curve of a gillnet. Rbyn. Khoz., 45, 56-58.

Stergiou, K. I. \& Erzini, K. (2002). Comparative fixed gear studies in the Cyclades (Aegean Sea): Size selectivity of small-hook longlines and monofilament gillnets. Fisheries Research, 58, 25-40. DOI:10.1016/S0165-7836(01)00363-0

Soykan, O., İlkyaz, A. T., Metin, G. \& Kınacıgil, H. T. (2015). Growth and reproduction of Boops boops, Dentex macrophthalmus, Diplodus vulgaris and Pagellus acarne (Actinopterygii: Perciformes: Sparidae) from East-Central Aegean Sea, Turkey. Acta Ichthyologica et Piscatoria, 45, 39-55. DOI:10.3750/AIP2015.45.1.05 
STECF, (2015). Landing Obligation - Part 6 (Fisheries targeting demersal species in the Mediterranean Sea) (STECF-15-19). Publications Office of the European Union, EUR 27600 EN, JRC 98678, 268 p.

Tokaç, A., Herrmann, B., Gökçe, G., Krag, L. A., Nezhad, D. S., Lök, A., Kaykaç, H., Aydın, C. \& Ulaş, A. (2016). Understanding the size selectivity of red mullet (Mullus barbatus) in Mediterranean trawl codends: A study based on fish morphology. Fisheries Research, 17, 81-93. DOI:10.1016/j.fishres.2015.09.002

Tosunoğlu, Z., Doğanyılmaz, Y. \& Özbilgin, H. (2003a). Body shape and trawl codend selectivity for nine commercial fish species. Journal of the Marine Biological Association of the United Kingdom, 83, 1309-1313. DOI:10.1017/S0025315403008737

Tosunoğlu, Z., Doğanyılmaz, Y. \& Özbilgin, H. (2003b). Determination of the appropriate hanging ratios to ease the escape of juvenile red mullet (Mullus barbatus L., 1758) and annular sea bream (Diplodus annularis L., 1758) from trawl cod-end. Turkish Journal of Veterinary and Animal Sciences, 27, 1193-1199.
Tosunoğlu, Z., Aydın, C., Metin, G., Kaykaç, M.H. \& Düzbastılar, F. O. (2018a). Researches on Izmir Bay (Aegean Sea, Turkey) purse seine fishery (in Turkish). Ege University Scientific Research Project Coordination Unit, Project No: 2017/SUF/002, 75 p (Unpublished).

Tosunoğlu, Z., Karakuzu, R. O., Gökçe, G. \& Kaykaç, M. H. (2018b). Fish morphology and barrier trap bar spacing in lagoon fisheries along the Aegean Coast of Turkey. Mediterranean Fisheries and Aquaculture Research, 1, 49-56.

Tosunoğlu, Z., Düzbastılar, F. O., Kaykaç, M. H., Aydın, C., Metin, G. \& Güleç, Ö. (2020). Effect of Sorting Grid System on Izmir Bay Purse Seine Fishery: Species-Size Selectivity and Survival Rates (in Turkish). TUBITAK 1180317 Final Report, Ankara, 112 p (Unpublished).

Zar, J. H. (1999). Biostatistical analysis. 4 th ed. New Jersey, NJ, USA: Prentice- Hall, Upper Saddle River, New Jersey. 